\begin{tabular}{ll}
\hline 総 \\
\hline
\end{tabular}

\title{
WTO に抢ける漁業補助金交渉
}

\author{
八木信 行a*
}

(2007 年 10 月 1 日受付, 2008 年 4 月 24 日受理)

\section{水産庁}

Negotiation on fisheries subsidies at WTO Doha round

NOBUYUKI YAGI*

Fisheries Agency, Chiyoda, Tokyo 100-8907, Japan

The Doha Ministerial Declaration, adopted at the WTO Ministerial Conference in 2001, agreed to start negotiations aimed at clarifying and improving discipline on fisheries subsidies, taking into account the importance of this sector to developing countries. The Negotiation Group on Rules has regularly met in Geneva to fulfill the mandate. So far, there was broad agreement that the Group should strengthen discipline through the prohibition of certain forms of fisheries subsidies that contribute to overcapacity and over-fishing. However, several unresolved issues can be still identified. One is an issue on sustainable development. Specifically, the question "to what extent the WTO should incorporate the element of fishery resource conservation into its new discipline of fisheries subsidies" remains unresolved. This paper reviews current developments on the issue of fisheries subsidies discussed at the WTO, OECD, and other relevant international organizations.

キーワード : OECD, WTO, 漁業補助金, 貿易と環境,

補助金が貿易に悪影響を及ぼす点は，古くから国際社 会で認識されている。1 1948 年に発足したガット体制で は, 輸出補助金の交付を回避すべきとの規律が存在して おり（1947 年 GATT「関税と貿易に関する一般協定」 第 16 条), また, ガットを拡大発展させる形で 1995 年 に設立されたWTO（世界貿易機関）体制では「補助金 及び相殺措置に関する協定」が発効し，更に精緻な補助 金規律を有するようになった。

加えて, 2001 年から開始されたWTO ドーハ・ラウ ンド交渉では,「補助金及び相殺関税に関する協定」全 体の規律明確化と合わせて, 漁業補助金に関する規律を 改善するための交渉が進んでいる。交渉では, 補助金に よる資源の過剰漁獲問題を回避すべきとの論点も重要視 されているが，このような環境面への配慮はWTO と しては新しい課題であり, 活発な議論の対象となってい
る。

本稿は, WTO に抢ける漁業補助金交渉の現状と問題 点などをレビューするとともに, 本分野における漁業経 済的な研究課題についても若干の説明を加えるものであ る。

\section{漁業補助金がもたらす影響}

漁業補助金もたらす影響評価に関する代表的な研究と しては, OECD (経済協力開発機構)によるものがある。 ここでは，漁業資源管理が実施されている場合といない 場合に分けた上で，補助金の定性的な影響について，次 のような説明を行っている。22

ケース 1：輸出国側で漁獲規制が実施されていない場 合 ある輸出国において, 有効な漁獲規制が実施されて おらず，オープンアクセスに近い状態の漁業が存在する

* Tel/Fax : 81-3-5841-5599. Email : yagi@fs.a.u-tokyo.ac.jp

a 現所属: 東京大学大学院農学生命科学研究科 (Graduate School of Agricultural Life Sciences, The University of Tokyo Bunkyo, Tokyo 113-8657, Japan) 
(a)

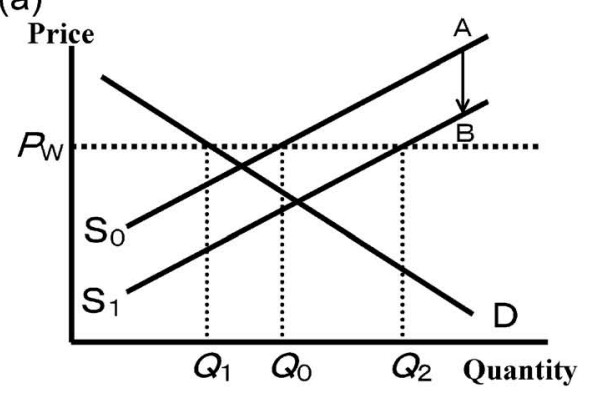

(c)

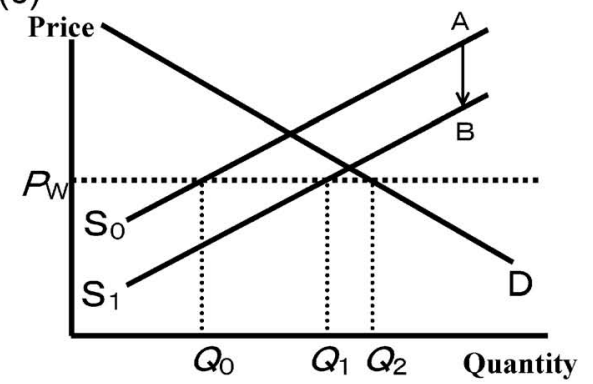

(b)

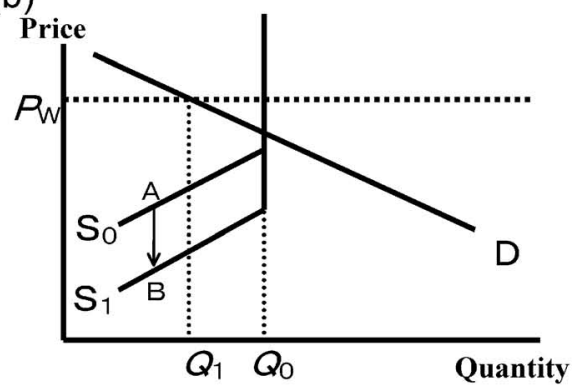

(d)

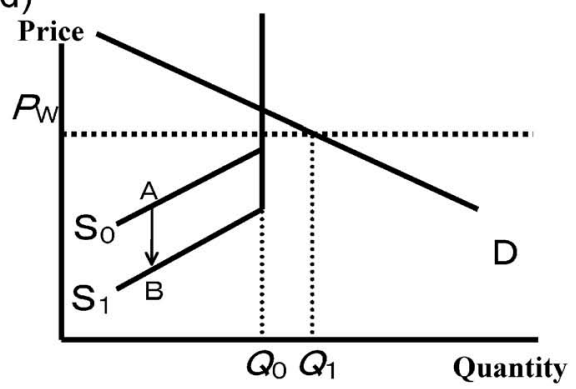

Fig. 1 Effects of subsidies for fishery harvesting sectors. (a) represents a situation in an exporting country where no fishery management is in place. (b) is a situation in an exporting country with effective fishery management in place. (c) indicates a situation in an importing country with no fishery management. (d) shows a situation in an importing country with effective fishery management. These diagrams are built on the OECD study. $\left.{ }^{2}\right)$

と仮定する（漁獲規制があっても，極端に大きな漁獲許 容量が設定されている場合は，この例に含まれる)。漁 獲対象の魚は世界で自由に取引されており，その国際価 格を $\mathrm{Pw}$ と抢く。図 1 に示すように, 補助金が存在しな い場合の供給曲線を $\mathrm{S}_{0}$ とすると，その国に抢いては魚 の供給は供給曲線が $\mathrm{P} \mathrm{w}$ と交差する点まで行われる。そ の場合, 供給量は $\mathrm{Q}_{0}$ である。しかしながら魚の国内価 格は国際価格 Pw と同じであるため, 国内需要は, 需要 曲線 $\mathrm{D}$ が $\mathrm{Pw}$ と交差する点, すなわち $\mathrm{Q}_{1}$ しか存在しな い。 $\mathrm{Q}_{0}$ と $\mathrm{Q}_{1}$ の差が輸出に回されることになる。

ここで当該輸出国が補助金を拠出する場合を仮定す る。補助金は単位当たりの生産に対し $\mathrm{AB}$ の額だけ支払 われるとする。すると生産コストが下がるので供給曲線 $\mathrm{S}_{0}$ は, $\mathrm{AB}$ 分だけ押し下げられ, 新しく供給曲線 $\mathrm{S}_{1}$ と なる。その場合の供給量は, $\mathrm{Q}_{2}$ となる（その国の生産 量増加は世界の生産量と比較して十分に小さいので, 少 々の生産量の増加は世界の生産量全体に影響を与えない 範囲になると仮定)。この場合, 輸出国側では供給量が 増加し, その量は $\mathrm{Q}_{2}$ と $\mathrm{Q}_{0}$ の差となる。国内需要 $\mathrm{Q}_{1}$ は 変わらないので, 供給の増加分は全て輸出に回されるこ とになる。つまり, 補助金が, 生産を増加させ, 輸出を 増加させるよう作用する。

ケース $2:$ 輸出国側で漁獲規制が実施されている場合 図 2 に示すように, 有効な漁獲制限が存在する場合 は, 供給の上限量は $\mathrm{Q}_{0}$ である。つまり, 供給曲線は $\mathrm{Q}_{0}$
まで来ると直立する形になる。補助金が存在しない場合 の供給曲線を $\mathrm{S}_{0}$ とすると, その国においては魚の供給 量は $\mathrm{Q}_{0}$ となる。国内需要は $\mathrm{Q}_{1}$ であるから $\mathrm{Q}_{0}$ と $\mathrm{Q}_{1}$ の 差が輸出に回されることになる。

補助金を拠出する場合でも, 供給量は漁獲制限の数量 $\mathrm{Q}_{0}$ で固定されているため, 輸出に回る量は増加しな い。つまり, 補助金の影響は存在しないことになる。

ケース $3:$ 輸入国側で漁獲規制が実施されていない場 合 続いて輸入国側における補助金の影響を説明する (以下は筆者独自の分析である。)

ある輸入国において, 有効な漁獲規制が実施されてお らず，オープンアクセスに近い状態の漁業が存在すると 仮定する（漁獲規制があっても, 極端に大きな漁獲許容 量が設定されている場合は, この例に含まれる)。図 3 に示すとおり, 魚の国内価格は国際価格 Pw と同じであ るため, 国内需要は $\mathrm{Q}_{2}$ となる。国内供給量は $\mathrm{Q}_{0}$ であ るため, $\mathrm{Q}_{0}$ と $\mathrm{Q}_{2}$ の差が，輸入量となる。

ここで補助金を拠出する場合は供給量が $\mathrm{Q}_{1}$ となり, この結果 $\mathrm{Q}_{1}$ と $\mathrm{Q}_{0}$ の差の分だけ, 輸入国側では供給量 が増加する。国内需要 $\mathrm{Q}_{2}$ は変わらないが, 輸入量は減 ることになる（減少する量は $\mathrm{Q}_{1}$ と $\mathrm{Q}_{0}$ の差）。つまり， 補助金が, 生産を増加させ, 輸入を減少させるよう作用 する。

ケース 4: 輸入国側で漁獲規制が実施されている場合 有効な漁獲規制が存在する場合, 図 4 に示すとおり, 
供給曲線は $\mathrm{Q}_{0}$ まで来ると直立する形になるため, 供給 の上限量は $\mathrm{Q}_{0}$ となる。補助金が存在しない場合の供給 曲線を $\mathrm{S}_{0}$ とすると，その国に抢いては魚の供給量は $\mathrm{Q}_{0}$ となる。魚の国内価格は国際価格 $\mathrm{Pw}$ と同じであるた め, 国内需要は $\mathrm{Q}_{1}$ まで存在する。 $\mathrm{Q}_{0}$ と $\mathrm{Q}_{1}$ の差が輸入 である。

補助金を拠出する場合も, 供給量は漁獲制限の数量 $\mathrm{Q}_{0}$ で固定されているので，供給量は増加せず，従って 輸入量も減少しない。つまり, 補助金の影響は存在しな いことになる。

漁業補助金と他の補助金の差異 以上 4 つの典型例 からは, 漁業の場合, 有効な漁獲規制を行っているか否 かによって補助金が及ぼす影響が異なっていることが分 かる。他の鉱工業品生産では, 通常は政府による生産総 量規制などはなされておらず，従って補助金が常に生産 量や貿易量に影響を及ぼす状況が存在していることから 考えれば，漁業補助金が特異な性質を有していることが 分かる。

UNEP やFAO などにおける議論の状況漁業補助 金がもたらす影響についての議論は, OECD 以外の国 際機関でもなされている。

UNEP（国連環境計画）では，漁業補助金に関する研 究に 1997 年から着手し, 毎年のようにワークショップ 等を開催している。UNEPは，補助金による資源への 影響は，漁獲制限をしているか否かによって異なるとし て，各状況に分けて影響を判断するための「マトリック ス・アプローチ」を提唱している。3) 漁業補助金がもた らす影響は, 資源管理の有無により異なるとの議論の方 向性は，OECDによる分析と同じ趣旨であると考えて 差し支えない。

また， 2002 年 9 月の WSSD（持続的開発に関する世 界サミット）で採択された文書には, IUU（違法・無 報告・無規制）漁業と過㮃漁獲能力につながる補助金の 撤廃を求める内容が含をれた。出この文章の内容は, 後 述する 2005 年の WTO 香港閣僚宣言内容にも色濃く反 映されている。

更に, 2003 年 6 月の $\mathrm{G} 8$ サミット（フランス・エビ アンで開催）においても，漁業補助金を含む補助金及び 相殺関税に関する協定の規律の明確化, 改善というドー 八での約束の再確認等が, サミット付属文書に記載され た（農林水産省 http://www.maff.go.jp / www / press / cont/20030604summit.htm)。

FAO（世界食糧農業機関）に抢いても，2000年 11 月及び 2002 年 12 月に開催された漁業補助金専門家会 合から漁業補助金を巡る議論が本格化した。去）専門家会 合とは, FAO が選定する 10 名程度の専門家が政府の 立場から離れて議論する趣旨の会合であるが，この 2 回の会合では, 補助金の範囲をWTOの規定よりも広
く取り, 例えば, 調査研究や漁港建設は漁業者が本来自 費で行うべきところを政府が肩代わりしているのでこれ も補助金と見なすべき，といった専門家の見解が示され た。しかしながら，この議論は，2003 年 2 月に開催さ れた第 25 回 $\mathrm{FAO}$ 水産委員会に打いては, 漁業補助金 の範囲などについて各国からの合意は得られなかった。7) また， 2004 年に開催された漁業補助金に関する政府間 技術会合に抢いても，漁業補助金の定義などに関し加盟 国の合意を得るまでには至らなかった。8)なお，FAOで は，その後，漁業補助金に関する組織だった作業を行っ ておらず，2007 年時点までその状況が続いている。

\section{世界の漁業補助金総額}

続いて，世界の漁業補助金がどの程度の金額であるの か，議論を整理したい。

WTO による漁業補助金情報 WTO は,「補助金及 び相殺措置に関する協定」第 25 条で, 加盟国に補助金 の通報義務を課している。しかしながら，WTO 通報か らは，加盟国の漁業補助金の総額が何ドルになるかとい った推定を行うことは技術的に困難である。

まず，WTO では，「漁業」補助金の定義が明確化さ れていないとの障害が存在する。補助金自体の定義は, 協定の第 1 条に示されており，金銭的給付だけでな $く$, 貸付, 出資, 債務保証, 免税措置なども補助金に含 むとしている。しかしながら，「漁業」補助金が具体的 にどこまでの分野の補助金を指すのか, 例えば加工や流 通まで含むのかなぞ, 明確な規定が存在しているわけで はない。また, WTO 補助金協定第 2 条では, 特定の産 業グループなどに支払われる補助金，いわゆる「特定性 (specificity)」を有する補助金だけが通報義務の対象々 なっているが，「特定性」の判断基準は実質的には加盟 国に委ねられているという状況も存在する。つまり, 同 じような種類の補助金であっても, 加盟国間で通報状況 が異なる余地が存在しているのである。

OECD 政府財政移転統計 OECD では，1996 年以 降, 毎年, 加盟国から水産業に関する様々な統計情報を 収集している。この中に「政府財政移転 (Government Financial Transfers)」の金額統計が存在する。加盟国 の漁業に関係する政府財政移転の額を単純に足し合わせ れば， 1996 年から 2003 年までの間，この年間額は 54 〜68 億ドルとなる。2)

このデータは, 世界の漁業補助金総額の 1 つの目安 にはなると思われるが，集計範囲は OECD 加盟国に限 定されている点, また，OECD でいう政府財政移転の 定義は, 漁業政策に伴い各国が行う政府介入の金銭価值 というものであり, ${ }^{2)}$ WTO でいう補助金とは必ずしも 内容が一致しない点には留意する必要がある。更には, WTO と同様，OECD に抢いても，国によって通報する 
Table 1 Estimated amounts of total fisheries subsidies in the world

\begin{tabular}{lcccc}
\hline & WTO & $\begin{array}{c}\text { OECD } \\
(2006)\end{array}$ & $\begin{array}{c}\text { Milazzo } \\
(1998)\end{array}$ & $\begin{array}{c}\text { Smaila } \\
\text { \& Pauly } \\
(2006)\end{array}$ \\
\hline $\begin{array}{l}\text { Estimated amount of total } \\
\quad \text { subsidies }\end{array}$ & N/A & $\begin{array}{c}5.4-6.8 \\
\text { Billion }\end{array}$ & $\begin{array}{c}\text { USD } \\
\text { Billion }\end{array}$ & $\begin{array}{c}\text { USD } \\
\text { Billion }\end{array}$ \\
\hline $\begin{array}{l}\text { Direct payment for } \\
\quad \text { fishermen }\end{array}$ & $\triangle$ & $\bigcirc$ & $\bigcirc$ & $\bigcirc$ \\
$\begin{array}{l}\text { Support for fixed and } \\
\text { variable costs }\end{array}$ & $\triangle$ & $\bigcirc$ & $\bigcirc$ & $\bigcirc$ \\
$\begin{array}{l}\text { Tax exemption } \\
\text { Price support }\end{array}$ & $\triangle$ & $\times$ & $\bigcirc$ & $\bigcirc$ \\
Other indirect support & $\triangle$ & $\times$ & $\bigcirc$ & $\bigcirc$ \\
Research and development & $\triangle$ & $\bigcirc$ & $\bigcirc$ & $\bigcirc$ \\
Infrastructure & $\times$ & $\bigcirc$ & $\bigcirc$ & $\bigcirc$ \\
Foreign access payment & $\triangle$ & $\bigcirc$ & $\bigcirc$ & $\bigcirc$ \\
Uncollected resource rent & $\times$ & $\times$ & $\bigcirc$ & $\bigcirc$ \\
\hline
\end{tabular}

shows that the item is included in the estimation, while $\times$ shows it is not. $\triangle$ in the column of the WTO shows that data is collected only if such a subsidy is "specific" in accordance with the provisions of the Agreement on Subsidies and Countervailing Measures (ASCM). The estimation of the OECD only contains subsidies paid by OECD members.

補助金の範囲が異る可能性もある。例えば，漁港関係予 算の場合, 日本の場合は水産庁の予算になっていること から OECD に通報を行っているが，他国では水産部局 が所管しない予算であるなどのために通報されていない 可能性もある。通報済みの補助金額と, 実際の補助金額 が異なる余地は，WTO の場合と同じく OECD にも存 在する。

独立の研究者による推定 以上のように，漁業補助金 に関する通報を加盟国から直接受け取っている国際機関 であっても，全世界の漁業補助金総額を公式に推計した 例はない。他方，独立した研究者は，世界における年間 漁業補助金総額について様々な推定を行っている。 Milazzo9) がこれを 140-205 億ドル, Smaila \& Pauly ${ }^{10)}$ では 300-340 億ドルと推定しているのは，この例であ る（表 1 )。研究者により推定金額にばらつきが存在す るが，これは，使用する補助金の定義（すなわち補助金 の範囲）の不一致や，データを引き延ばす手法の差異な ぞによるものであろう。また，一部の推定では，不正確 な内容の資料を，そのまま無批判に引用しているという 問題も見られる。

いずれにせよ，現下の状況では，世界の漁業補助金の 総額に関し定説がある状況ではないといえる。

\section{WTO ドーハ・ラウンド交渉における議論の状況}

以上の知見をふまえて, 以降, WTO における漁業補 助金交渉の現状をレビューしていきたい。
ドーハ・ラウンド開始前の状況 WTO では， 1990 年代から, 漁業補助金による貿易丕曲や, 環境への悪影 響などを問題視する議論が見られるようになった。 1999 年 3 月にジュネーブで開催されたWTO「貿易と 環境八イレベル・シンポジウム」で, 米国などが, 貿易 歪曲的で環境破壊的な漁業補助金の撤廃を主張したのも この一例である。貿易歪曲は WTO の従来的な関心事 項であり, ことさら説明する必要はないと思われるが， 海洋環境の破壞をWTO で問題視し始めた背景につい ては若干説明が必要であると思われる。

当時は, 環境 NGO (非政府組織) が反グローバリゼー ション活動を開始していた時期であった。また，1998 年 10 月に, WTO 上級委員会が, ウミガメを致死させ る漁法で生産されたエビを禁輸する米国の貿易措置に対 しクロ判定を下す事例があった。 張する米国の環境団体などはこれに敏感に反応し, WTO に対する反発を強めていた。実際, 米国のシアト ルで開催された第 3 回 WTO 閣僚会合（1999年 12 月） の場外では, グローバリズムに反対する NGO が大がか りなデモを行ったが, その際, 参加者の一部がウミガメ の衣装を着てパフォーマンスを繰り広げていた場面も見 られた。

しかしながら一方で, 環境 NGO は, 漁業補助金につ いてはWTOに期待していた。実際, 先述のWTO「貿 易と環境八イレベル・シンポジウム」で環境 NGO は, 法的拘束力を持つWTO が漁業補助金に取り組むこと を歓迎する演説を行っている。

このような状況に呼応するように, シアトル閣僚会合 の直前, 米国国務省や USTR の担当官も, 「WTO の交 渉分野候補は数多くあるが, NGO の説得に使える案件 は漁業補助金だけであるので，この分野は新ラウンドの 要素として極めて重要な分野だ」と力説していた（当時 筆者が米国担当官から直接取材)。結局, シアトルでの 閣僚会合は, 宣言案に合意ができずに終わり，WTO の 新しいラウンド交渉（多角的通商交渉）が開始できない 事態となったが，漁業補助金に関する米国側の考えは， 引き続き維持された。

WTO ドーハ閣僚宣言 シアトルに抢ける閣僚会合の 失敗後, 2001 年 11 月にカタールのドー八で開催された 第 4 回 WTO 閣僚会合は, 閣僚宣言を採択し, 12)この閣 僚宣言に基づき, WTO ドーハ・ラウンド交渉が立ち上 がった。

閣僚宣言に抢ける漁業補助金の記述は，「現行補助金 協定の原則や効果を維持し」,「途上国における漁業セク ターの重要性を考慮しつつ, 漁業補助金に関するWTO の規律を明確化し向上させることを目標とすべき」との ものであった。なお，この内容は，ルール交渉部分と環 境部分の 2 力所に重複して書き込まれて抢り, 宣言案 
Table 2 Comparison of top-down and bottom-up approaches debated at the negotiation on fisheries subsidies at the WTO

\begin{tabular}{lll}
\hline & \multicolumn{1}{c}{ Top-down } & \multicolumn{1}{c}{ Bottom-up } \\
\hline Approach & $\begin{array}{l}\text { All fisheries subsidies should be prohibited. Excep- } \\
\text { tions from the prohibition may be specified in the } \\
\text { list. }\end{array}$ & $\begin{array}{l}\text { Only prohibited subsidies should be clearly speci- } \\
\text { fied and listed. Other subsidies should not be pro- } \\
\text { hibited. }\end{array}$ \\
\hline Supporting arguments & $\begin{array}{l}\text { Discipline is strong, simple and enforceable. Broad } \\
\text { prohibition is achievarable. No need for revising } \\
\text { rules when a new harmful subsidy is introduced. }\end{array}$ & $\begin{array}{l}\text { Existing rules are based on the bottom-up ap- } \\
\text { proach, and preserving this concept is necessary to } \\
\text { keep consistency with the Doha Declaration. The } \\
\text { WTO Hong-Kong Declaration also implies a bot- } \\
\text { tom-up approach by specifying the prohibited sub- } \\
\text { sidies. }\end{array}$ \\
\hline Opposing opinions & $\begin{array}{l}\text { No agreement exists for broad prohibition. Careful } \\
\text { consideration is needed before introducing the top- } \\
\text { down approach, because it could be a horizontal } \\
\text { standard for whole set of entire subsidy rules. }\end{array}$ & $\begin{array}{l}\text { When a new harmful subsidy is introduced in the } \\
\text { future, such subsidies may not be subject to prohi- } \\
\text { bition, and potential loopholes in the discipline may } \\
\text { exist. }\end{array}$ \\
\hline
\end{tabular}

Table 3 Summary table of the proposed discipline on subsidies for marine capture fisheries from 2005 to 2007 at the WTO negotiations

\begin{tabular}{|c|c|c|c|c|c|c|c|}
\hline Proposed countries & $\mathrm{EC}$ & $\begin{array}{c}\text { New } \\
\text { Zealand }\end{array}$ & Brazil & Norway & USA & $\begin{array}{l}\text { Japan, Korea, } \\
\text { Chinese Taipei }\end{array}$ & Indonesia \\
\hline Approach & Bottom-up & Top-down & Top-down & Bottom-up & Top-down & Bottom-up & Bottom-up \\
\hline Vessel construction & $x$ & $x$ & $x^{*}$ & $x^{* * *}$ & $x$ & $\triangle$ & $\triangle$ \\
\hline Vessel modification & $\triangle$ & $\triangle$ & $\triangle$ & - & $\triangle$ & $\triangle$ & $\triangle$ \\
\hline Vessel transfer to third countries & $\times$ & $x$ & $\times$ & - & $\times$ & $\times$ & $\triangle$ \\
\hline Foreign access payment & - & 0 & $\triangle$ & - & $\triangle$ & $\triangle$ & $\triangle$ \\
\hline Income or price support & - & $\times$ & $\times$ & - & $\times$ & - & $\triangle$ \\
\hline Support for fixed and variable costs & - & $x$ & $x^{* *}$ & - & $\times$ & - & $\triangle^{*}$ \\
\hline Monitoring and surveillance & - & - & - & - & $\bigcirc$ & $\bigcirc$ & $\bigcirc$ \\
\hline Vessel decommission & $\bigcirc$ & $\triangle$ & $\triangle$ & $\triangle$ & $\triangle$ & $\triangle$ & $\triangle$ \\
\hline Support for temporal cessation of fishing & - & - & $\bigcirc$ & - & $\bigcirc$ & $\bigcirc$ & $\bigcirc$ \\
\hline Support for retirement program & - & $\bigcirc$ & $\bigcirc$ & - & $\bigcirc$ & $\bigcirc$ & $\bigcirc$ \\
\hline Research and development & - & $\bigcirc$ & $\bigcirc$ & - & $\bigcirc$ & $\bigcirc$ & $\bigcirc$ \\
\hline Resource enhancement & - & $\bigcirc$ & $\bigcirc$ & - & $\bigcirc$ & $\bigcirc$ & $\bigcirc$ \\
\hline Disaster relief & - & $\bigcirc$ & $\bigcirc$ & - & $\bigcirc$ & O & $\bigcirc$ \\
\hline Infrastructure & - & $\bigcirc$ & $\bigcirc$ & - & $\triangle$ & $\bigcirc$ & $\bigcirc$ \\
\hline Special treatment for small-scale fisheries & - & $\begin{array}{l}\bigcirc \text { for } \\
\text { artisanal }\end{array}$ & $x^{* *}$ & 0 & Unclear & 0 & $\triangle^{*}$ \\
\hline
\end{tabular}

$\bigcirc$ denotes that the subsidy is permitted. $\triangle$ shows permitted under certain conditions (such as the placement of fishery management systems). $\times$ indicates prohibition. $x^{*}$ means $\times$ for developed countries and $\triangle$ for developing countries. $x^{* *}$ means $\times$ for developed countries and $\bigcirc$ for developing countries. $x^{* * *}$ means $\times$ for large-sized vessels, but $\triangle$ for small vessels. $\triangle^{*}$ means $\triangle$ for developed countries and $\bigcirc$ for developing countries.

の中でも比較的高い関心を引くものとなっていた。

WTO ルール交渉（交渉初期の状況）ドー八閣僚会 議以降, スイス・ジュネーブの WTO 本部では, ほぼ 毎月のようにWTO ルール交渉が開催され，ここで漁 業補助金問題が議論されるようになった。

交渉開始後, 最初の 1 年（概ね 2002 年 4 月から 2003 年初頭まで）は，各国が漁業補助金がもたらす影 響を概念的に主張しつつ, 漁業補助金の定義や, 交渉の 進め方に関して意見を述べ合う状況であった。とりわ け，米国, 13,14) ニュージーランド, 15,16)などは, 補助金 が漁業にもたらす悪影響を所与のものとして規制を強め ようとしていたのに対し, 日本 ${ }^{17)}$ や韓国 ${ }^{18)}$ が，実際の
データを基にして慎重に議論を行うべきとの主張を行 い，関係国による意見の相違が目立つ状況であった。

WTO ルール交渉（2003 年米国提案を境亡した転機） 2003 年 3 月, 米国は, 従来の概念的な議論から一歩進 久, 漁業補助金の規律方法に関し具体案を示し, 禁止補 助金の拡大やダーク・アンバー補助金の設定を提案し た19）(WTOに打ける補助金の分類は表 2 を参照）。ま た EC も, 漁船建造補助金は禁止対象とするが, 減船補 助金などは許容すべき20) と具体的な提案を行った。こ れらの提案には賛否両論が出され, また禁止補助金の範 囲についても各国が様々な意見を表明し, 意見の収斂は 見られない状態が続いた。 
WTO ルール交渉（カンクン閣僚会合以降） メキシ コのカンクンで 2003 年 9 月に開催された第 5 回 WTO 閣僚会議は, 結局閣僚文書を採択せず決裂した。決裂原 因はルール交渉以外の交渉分野にあったが，結果的に, 漁業補助金問題についての合意も成立しない状態となっ た。このカンクン会合以降, 半年程度ラウンド交渉が中 断した時期を経て，ルール交渉は，2004 年 3 月から再 開された。

この頃から，2つの補助金規律方式，すなわち，一旦 全ての漁業補助金を禁止し，その例外だけを列挙する方 式（トップダウン方式と呼ばれる）と，禁止補助金を列 挙すれば済むとする方式(ボトムアップ方式と呼ばれる) が対立する構図が生じ始めた（両方式の詳細は表 3 を 参照）。これは, 2004 年 4 月の, ニュージーランドによ るトップダウン方式提案 ${ }^{21)}$ に端を発しており, 以降, 反対・賛成双方の立場で複数の文書が提出された。トッ プダウン方式に賛成する文書として，アルゼンチンなど による 6 力国提案, ${ }^{22}$ 米国による提案, ${ }^{23)}$ ブラジル提 案 ${ }^{24)}$ な゙゙が提出され, 他方で, トップダウン方式に反 対する内容としては, 日本提案, ${ }^{25,26)}$ 日本・韓国・チャ イニーズタイペイ共同提案 27$)$ が提出されている。

なお，後者も，補助金を規律すること自体には反対し て抢らず，例えば，資源管理が不十分な場合の漁船建造 補助金や，IUU 漁業につながる補助金などは禁止すべ きと述べている26,27)が, 同時に, 補助金が漁業生産を増 加させるかどうかは更に精查が必要, といった指摘を行 っている。25)この時期の議論では, どちらかといえばト ップダウン方式を支持する国の方が多い状況であった。

WTO ルール交渉（香港閣僚会合から 2007 年秋まで） 香港で 2005 年 12 月に開催した第 6 回 WTO 閣僚会合 では, 閣僚宣言が採択された。この宣言文では, 漁業補 助金に関し，過䛢漁獲能力や過剩漁獲につながる補助金 を禁止することを含め, 規律の強化に広範な合意がある こと, また, 今後は透明性及び実施可能性を含めて補助 金規律の性格や範囲を確立させるための作業を早急に行 うことが確認された。28)

この香港閣僚会合の前後から, 各国は補助金規律の具 体的な条文案を提案するようになった。まず，2005 年 11 月にブラジルが提案を提出し，4回の修正を経て, 現在に至っている。29) また， 2006 年 3 月，ニュージー ランドも条文案を提出し, これを同年更に加筆修正し, 現状となっている。 ${ }^{30)} 2006$ 年 4 月には, 日本・韓国・ チャイニーズタイペイが共同提案「漁業補助金規律の骨 子」を提出。こちらも 2 回の修正を経て現状となって いる。31) 同じく2006年 4 月, EC も条約案を提示し た。 32 更に 2006 年 6 月, アルゼンチンは, S \& D 部分 だけの条文案「漁業補助金 : 特別かつ異なる扱い」を提 案し、これを 2007 年に修正し, 現在に至っている。33)

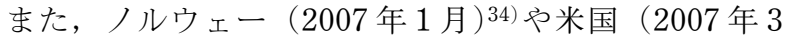
月)35) も，それぞれ条文案を提出した。最後に，インド ネシアが 2007 年 7 月に条文案を提案し, こちらも修正 版提出を経て現状となっている。36)

各提案の概要は表 4 に示すと抢りであり, 規律の対 象を海面漁獲漁業に限る点（従って, 養殖業, 陸上での 水産加工業, 内水面漁業は, 条件付きながら規律の適応 外となる方向）などは，かなり意見の収斂が見られてい る。また, 海面漁獲漁業に対する補助金でも, 調查研究 や資源増大などのために支出する補助金は拠出を認める 点などは，概ね意見の集約が見られている。

しかしながら，規律方式（トップダウンかボトムアッ プか) や, 海面漁獲漁業に打いて漁船建造補助や燃油補 助などを禁止対象とするかどうかなどについては, 提案 によって違いが顕著である。

なお，ラウンド交渉は，2006 年 6 月の時点で, 農業 交渉などの主要部分の交渉進展が見られない等として交 渉を一旦凍結し， 2006 年 12 月頃まで半年程度中断状態 が続いた後再開し，現在 (2007 年 9 月) に至っている。 本稿は, ラウンド交渉のうち 2007 年 9 月までの状況の みを反映している点を断っておきたい。

\section{交渉の問題点と今後の研究課題}

WTO と環境 以上述べてきたとおり，この交渉の特 徵は, 補助金による資源の過剩漁獲を回避すべきといっ た環境的な関心事項を扱っている点にあるといえる。貿 易と環境は，多国間で合意を形成することが極めて難し いテーマである。37,38) 補助金問題は, 従来的な意味でい う「貿易と環境」とはやや趣旨が異なる部分もあるが， WTO がどこまで環境問題に踏反込むべきかが議論とな っている点では同じ問題を共有しているといえる。実 際, 漁業補助金交渉は, WTO として環境を扱う最初の 規律を作成する交渉であるという意味を有しているとの 認識を示す参加者も複数存在している（筆者が交渉参加 者から直接取材)。

漁業資源を保全するという課題の本質は，補助金とい うよりも, むしろ漁業資源管理体制の問題である。これ は交渉でも頻繁に指摘されており, WTO が各国の漁業 資源管理体制にまで口出しすることの是非については各 国の意見の隔たりが存在している。この問題をどのよう に処理するかは, この交渉の一つの大きな課題であると いえよう。

開発か環境か 途上国への配慮は，ドー八閣僚宣言で も記載されており，適切な範囲でこれを行う必要がある 点を否定する交渉参加者はいない。しかしながら, 他方 で, 香港閣僚宣言では, 過剩漁獲能力や過剩漁獲への対 策を重視する姿勢を打ち出している。交渉では, 両者の 適切なバランスを見出す必要があるが，以下のと抢り， 
こちらも難航していると言わざるを得ない。

途上国の中では，補助金の交付を原則禁止にした上 で，途上国に対してのみ寛容な S \& D（特別かつ異な る扱い）を要求するものもある。すなわち，先進国は補 助金の拠出を認めないが，途上国は拠出を可能とするこ とで開発を加速させ，不平等を解消すべきという主張で ある。他方で, 先進国側は, 漁業の分野では, 世界の漁 獲漁業生産量ベスト 10 の国を順に並べると, 中国, ペ ルー, 米国, チリ, インドネシア, 日本, インド, ロシ ア，タイ，ノルウェーの順であり, ${ }^{39)}$ 途上国の方が，む しろ先進国をしのぐ生産を行っている, 従って, 鉱工業 の分野で言う途上国の概念を漁業の分野にそのまま当て はめて議論を行うことは適当ではない，とする議論も行 っている。途上国は, 先進国と比較して, 漁業管理制度 や取締体制も良く整備されていない場合が多く，このよ うな国で更に漁獲能力が高まれば，短期的には水産物の 生産量が上昇しても，長期的には過唾漁獲により生産は 減少に向かう危険も存在する, との議論も出されている。

これに対しては，途上国側からも，漁業管理制度を整 備するためには先進国からの技術協力が不可欠であるの で，この枠組みをWTO で構築する必要があるとの意 見も強く, 最終的な解決は図られていない。

また，途上国といっても，大規模な漁業国から，小規 模な島嶼国まで幅広く存在しており，小規模な国の方 は, 相当程度の優遇策が取れるべきとの考えも存在す る。実際, 具体的な解決策の 1 つして, 大規模な漁 業生産を行っている途上国と，そうでない途上国を分け て規律すればどうか，といったアイディアが先進国側か ら提起されたこともある。しかしながら，WTOに打い ては, 漁業補助金案件で途上国が分断される前例を作れ ば，他の交渉分野でもこれが起こるのではないかと考え る一部の途上国が強く反発し，この方法も，合意形成の 見込みは極めて薄い状況にある。

開発と環境の問題についての解決は, 交渉のもう一つ の大きな課題であるといえよう。

交渉に参加する各国は本音を表明しているのか否か また，この交渉が WTO のラウンド交渉の一部である ために生じている問題点も存在する。ラウンド交渉で は, 農業交渉, 非農産品市場アクセス交渉, サービス交 渉, そして漁業補助金を扱うルール交渉など, 複数の分 野が並行して進んで抢り, 最終的には全ての分野が一括 受諾されることになっている。またルール交渉でも, 漁 業補助金だけでなく，一般補助金及びアンチダンピング も並行して議論がなされている。このような中では, 参 加国が，ある分野で敢えて本音と異なるポジションをと り，別の分野での交渉で駆け引き材料（いわゆるレバレ ッジ）に使用することもあり得る。特に各国は, 環境と 貿易や環境と開発などの地球的規模の問題で最適なバラ
ンスを犠牲にしても，WTO 交渉全体での自国の譲歩を 最小限に食い止めることを優先させている可能性があ り，各国の表面的な態度を真に受けることができない場 合もある。WTO 漁業補助金交渉を取り巻く状況がこの ようなものである点も，最後に指摘しておきたい。

漁業経済研究における今後の課題 以上, 漁業補助金 を巡る国際的な検討の状況, 特にWTOにおける交渉 の現状と問題点などを紹介してきたが，最後に，今後の 研究課題についても触れておきたい。

この分野，すなわち，漁業補助金と漁業資源の関係に ついては, 漁業経済的な実証研究のレベルで全くと言っ ていいほど先行研究がないのが現状である。先に紹介し た OECDにおける研究についても, 短期的な均衡モデ ルを仮定した定性的な分析であり，長期の供給モデルを 活用して研究を行った例や, 実存する漁業統計や補助金 のデータなどを用いて定量的に分析した例はほとんど報 告されていない。関連する国際会議において適切な議論 の土台を提供するためにも, このような分野の研究が積 極的になされるべきではないだろうか。

\section{文献}

1）外務省経済局国際機関第一課.「解説 WTO 協定」日本国 際問題研究所, 東京. 2003.

2) OECD. The Financial Support to Fisheries: Implications for Sustainable Development. OECD Publications, Paris. 2006.

3) UNEP. Analyzing the Resource Impact of Fisheries Subsidies: A Matrix Approach. United Nations Publication, Geneva. 2004.

4) Report of the World Summit on Sustainable Development, Johannesburg, South Africa 26 August-4 September. United Nations (A/CONF. 199/20). New York. 2002.

5) FAO. FAO Expert Consultation on Economic Incentives and Responsible Fisheries, Rome, 28 November-1 December 2000. FAO Fisheries Report, No. 638. Rome. 2001.

6) Report of the Expert Consultation on Identifying, Assessing and Reporting on Subsidies in the Fishing Industry, Rome, 3-6 December 2002. FAO (COFI/2003/Inf. 12). Rome. 2003.

7) FAO. Report of the twenty-fifth session of the Committee on Fisheries, Rome, 24-28 February 2003. FAO Fisheries Report, No. 702. Rome. 2003.

8) FAO. Report of the Technical Consultation on the Use of Subsidies in the Fisheries Sector, Rome, 20 June-2 July 2004. FAO Fisheries Report, No. 752. Rome. 2004.

9) Milazzo, M., Subsidies in World Fisheries: A Re-Examination. World Bank Technical paper No. 406. Washington D.C. 1998.

10) Sumaila U R, Pauly D. Catching More Bait: A bottom-up re-estimation of global fisheries subsidies. Fisheries Center Research Report, University of British Colombia, Canada. 2006.

11) Report of the Appellate Body: United States - Import Prohibition of Certain Shrimp and Shrimp Products. WTO (WT/DS58/AB/R), Geneva. 1998.

12) Ministerial Declaration, Doha Ministerial Conference 914 November, 2001. WTO (WT/MIN (01)/DEC/W/1), 
Geneva. 2001.

13) Australia, Chile, Ecuador, Iceland, New Zealand, Peru, Philippines, and the United States. The Doha Mandate to Address Fisheries Subsidies. WTO document TN/RL/W /3, Geneva. 2002.

14) The United States. Adverse Trade and Conservation Effects of Fisheries Subsidies. WTO document TN/RL/ W/21, Geneva. 2002.

15) Argentina, Chile, Iceland, New Zealand, Norway, and Peru. Subsidies in the Fisheries Sector: Possible Categorizations. WTO document TN/RL/W/58, Geneva. 2003.

16) New Zealand. Fisheries Subsidies: Limitations of Existing Subsidy Disciplines. WTO document TN/RL/W/12, Geneva. 2002.

17) Japan. Japan's Contribution to Discussion on Fisheries Subsidies Issue. WTO document TN/RL/W/52, Geneva. 2003.

18) The Republic of Korea. Korea's Views on the Doha Development Agenda Discussions on Fisheries Subsidies. WTO document TN/RL/W/17, Geneva. 2002.

19) The United States. Possible Approaches to Improved Disciplines on Fisheries Subsidies. WTO document TN/RL/ W/77, Geneva. 2003.

20) European Communities. Submission of the European Communities to the Negotiating Group on Rules - Fisheries Subsidies. WTO document TN/RL/W/82. Geneva. 2003.

21) New Zealand. Fisheries Subsidies: Overcapacity and Over-exploitation. WTO document TN/RL/W/154. Geneva. 2004.

22) Argentina, Chile, Ecuador, New Zealand, Philippines, and Peru. Fisheries Subsidies. WTO document TN/RL/W/ 166. Geneva. 2004.

23) The United States. Additional views on the Structure of the Fisheries Subsidies Negotiations. WTO document TN /RL/W/169. Geneva. 2004.

24) Brazil. Contribution to the Discussion on the Framework for Disciplines on Fisheries Subsidies. WTO document TN/RL/W/176. Geneva. 2005.
25) Japan. Fisheries Subsidies: Proposed Structure of the Discussion. WTO document TN/RL/W/159. Geneva. 2004.

26) Japan. Proposal on Fisheries Subsidies. WTO document TN/RL/W/164. Geneva. 2004.

27) Japan; the Republic of Korea; and the Separate Customs Territory of Taiwan, Penghu, Kinmen, and Matsu. Contribution to the Discussion on the Framework for the Disciplines on the Fisheries Subsidies. WTO document TN/ RL/W/172. Geneva. 2005.

28) Ministerial Declaration, Hong-Kong Ministerial Conference, 22 December 2005. WTO (WT/MIN (05)/DEC, Annex D). Geneva. 2005.

29) Brazil. Possible Discipline on Fisheries Subsidies. WTO document TN/RL/GEN/79/Rev. 4, Geneva. 2007.

30) New Zealand. Fisheries Subsidies: Exhaustive List of Non-Prohibited Fisheries Subsidies. WTO document TN/ RL/GEN/141. Geneva. 2006.

31) Japan; the Republic of Korea; and the Separate Customs Territory of Taiwan, Penghu, Kinmen and Matsu. Fisheries Subsidies: Framework for Disciplines. WTO document TN/RL/GEN/114/Rev. 2. Geneva. 2007.

32) European Communities. Fisheries Subsidies. WTO document TN/RL/GEN/134. Geneva. 2006.

33) Argentina. Fisheries Subsidies: Special and Differential Treatment. WTO document TN/RL/GEN/138/Rev. 1. Geneva. 2007.

34) Norway, Fisheries Subsidies. WTO document TN/RL/ GEN/144. Geneva. 2007.

35) The Unites States. Fisheries Subsidies: Proposed New Disciplines. WTO document TN/RL/GEN/145. Geneva. 2007.

36) Republic of Indonesia. Fisheries Subsidies: Proposed New Disciplines. WTO document TN/RL/GEN/150/Rev. 1. Geneva. 2007.

37）田村次朗.「WTO ガイドブック」弘文堂, 東京. 2001.

38）中川淳司, 清水章雄, 平 覚, 間宮 勇.「国際経済法」 有斐閣, 東京. 2003.

39) The State of World Fisheries and Aquaculture 2006. FAO, Rome. 2007. 